\title{
Hepatitis B and $\mathbf{C}$ in pregnant women attended by a prenatal program in an universitary hospital in Rio de Janeiro, Brazil: retrospective study of seroprevalence screening
}

\author{
Monica Maia de Oliveira BARROS ${ }^{1}$, Karla Regina Oliveira de Moura RONCHINI ${ }^{2}$ and Rosa Leonôra Salerno SOARES ${ }^{2}$
}

Received 22/3/2018 Accepted 14/6/2018

ABSTRACT - Background - Hepatitis B and C are diseases with high morbimortality and constitute a global public health problem. In Brazil, the prevalence is not homogeneous, oscillating among different regions, but it is estimated that currently about $1 \%$ of the population present chronic disease related to the $\mathrm{B}$ virus and that there are 1.5 million infected with the $\mathrm{C}$ virus. Despite the development of hepatitis $\mathrm{B}$ vaccine, improvement in diagnostic methods and therapeutic advances in the field of viral hepatitis, there is still a large number of people who continues to be infected by these viruses, especially in populations at risk and also due to several factors, including vaccination and migration policies. Vertical and perinatal transmissions are of great importance in the epidemiology of viral hepatitis and the blood tests performed during prenatal care constitute a great opportunity for screening and identifying these viruses. Objective - To evaluate the seroprevalence of markers for B and C viruses in women who underwent prenatal care at the Hospital Universitário Antônio Pedro (Antonio Pedro University Hospital) from 2006 to 2013 and to compare the results found with regional data and those described in the specific literature. Methods - A descriptive, cross-sectional, quantitative study with retrospective data collected from 635 records of pregnant women attended at the Prenatal Service of the Hospital Universitário Antônio Pedro, Niterói, state of Rio de Janeiro, from March 2006 until December 2013. The database was built in the Microsoft Office Access program and was later exported to Microsoft Office Excel. For the processing and analysis of the data, it was used the SPSS (Statistical Package for Social Science, IBM) version 22.0, for Windows. Results Twelve cases with positive HBsAg (1.9\%), 189 cases with positive anti-HBs $(35.9 \%)$ and seven positive anti-HCV patients $(1.3 \%)$ were observed. There was no significant association between age and positivity for HBsAg, anti-HBs and anti-HCV $(P=0.205,0.872$ and 0.676 , respectively). There was a direct relationship between the anti-HBs positivity and the last four years of the study $(P<0.0001)$. Conclusion $-\mathrm{A}$ high prevalence of $\mathrm{HBsAg}$ was observed, higher than the expected for the evaluated region; there was a prevalence of anti-HCV, consistent with the current Brazilian reality; and a likely low rate of hepatitis $\mathrm{B}$ immunization, with a relatively high rate of susceptibility to this infection and no case of co-infection between $\mathrm{B}$ and $\mathrm{C}$ viruses and HIV. It is emphasized not only the need to trace hepatitis B and C, without exceptions, during prenatal care, since even though the current advances in therapy may not cure, at least they may allow a better quality of life for patients with chronic disease and the mandatory completion of immunoprophylaxis in all newborns. Special attention should be given to those patients susceptible to HBV, with prompt diagnosis and referral for specific vaccination.

HEADINGS - Seroepidemiologic studies. Hepatitis B. Hepatitis C. Pregnancy. Pregnant women.

\section{INTRODUCTION}

Hepatitis B virus (HBV) and $\mathrm{C}$ virus (HCV) are diseases with high morbimortality. HBV infection continues to be a global public health problem, with changes in its epidemiology due to several factors, including vaccination and migration policies. Approximately two billion people have been infected by $\mathrm{HBV}$, and 20 million are infected annually, existing about 240 million chronic carriers of this virus. The variable geographic prevalence is highest in Africa and $\mathrm{Asia}^{(1,2)}$.

In Brazil, despite the introduction of the vaccine in the Western Amazon in 1989 and progressive efforts of immunization and prevention by the Sistema Unico de Saúde (SUS), hepatitis B transmission is still a reality. The country was previously considered to be of intermediate endemicity, with great heterogeneity among regions and areas of high prevalence, especially in the Amazon Basin. Between 2004 and 2009, a populational study reported lower prevalence in all regions of Brazil. The most recent results indicated a reduced prevalence of hepatitis B throughout the country, classifying Brazil as being of low endemicity. Most studies showed a prevalence of $\mathrm{HBV}$ inferior to $1 \% \%^{(3-7)}$.

Although there is a $\mathrm{HCV}$ pandemic, its distribution is variable in different regions of the world. The World Health Organization (WHO) estimates that 3\% of the world's population is chronically infected with this virus and that 3-4 million people are infected each year, with 130-170 million chronic carriers at high risk of developing chronic liver disease, cirrhosis and hepatocellular carcinoma. Approximately 350,000 deaths occur each year due to HCV-related

Declared conflict of interest of all authors: none

Disclosure of funding: no funding received

${ }^{1}$ Universidade Federal Fluminense, Hospital Universitário Antônio Pedro, Serviço de Ambulatório, Rio de Janeiro, RJ, Brasil. ${ }^{2}$ Universidade Federal Fluminense, Faculdade de Medicina, Departamento de Medicina Interna, Rio de Janeiro, RJ, Brasil.

Corresponding author: Monica Maia de Oliveira Barros. Orcid: 0000-0002-2858-9596. E-mail: monica.maia1961@gmail.com 
liver disease. Although HCV infection incidence rate is apparently slowing in the developed world, deaths from liver diseases secondary to HCV will continue to increase over the next 20 years ${ }^{(8-10)}$.

Brazil, with about 1.5 million chronically infected people, is considered by the WHO as a country with intermediate density. The country has a vast territory with unequal population density and HCV incidence rates are variable, with the majority of cases concentrated in the most populated areas. Population-based and blood donor studies revealed lower prevalences than estimated, placing Brazil as low endemicity ${ }^{(4,11)}$. From 1999 to 2016, 319,751 cases of hepatitis $\mathrm{C}$ were detected in the country with anti-HCV or HCV-RNA reagents and 155,032 cases considering those that displayed both markers positive. Most of these cases were observed in the Southeast $(24.5 \%)$ and South $(5.5 \%)$ regions. This detection rate with anti-HCV and HCV-RNA reagents displayed a growth trend between 2003 and 2016 in all Brazilian regions. From 2015 on, cases were confirmed using only HCV-RNA, offering a more precise definition of an infection case, and consequently increasing the detection rate in all regions of the country. The number of deaths related to this etiology has increased over the years in all regions of Brazil $^{(4)}$.

The prevalence of $\mathrm{HBV}$ and $\mathrm{HCV}$ in a population is related to risk factors associated with the transmission, such as blood transfusion and blood products, dental and surgical procedures, use of tattoos, accidents with biological material, use of injectable substances, besides the sexual and vertical routes ${ }^{(12,13)}$.

Maternal-fetal transmission is of great importance in the epidemiology of viral hepatitis. In children of HBV infected mothers, vertical transmission carries a risk of progression to chronicity in $70 \%-90 \%$ of the cases ${ }^{(14,15)}$.

The present study had as objectives: to determine the seroprevalence of hepatitis B and C in the prenatal patients of the Hospital Hospital Universitário Antônio Pedro, Niterói, Rio de Janeiro; to compare the data found with the regional data and those described in the specific literature and to provide demographic, clinical and epidemiological data to the literature that may be used for the formulation of policies in the area.

There are few studies in national and international literature addressing the prevalence of hepatitis in pregnant women. As this is a still worldwide worrying and the early detection in prenatal care can avoid a series of deleterious outcomes for the pregnant woman and its child, the concern of deepening the study in this area arose with a more accurate evaluation of the epidemiological profile of pregnant women from the region. Thus, prenatal exams provide a great opportunity for screening and identifying these viruses in this population that could serve as a natural reservoir for future generations.

\section{METHODS}

A cross-sectional, descriptive study of the quantitative type with retrospective data collection was carried out, with medical records of pregnant women who attended the Prenatal Service of the Hospital Universitário Antônio Pedro (HUAP) from March 2006 to December 2013. The hospital, located in Niterói, attends patients from the Metropolitan Region II of Rio de Janeiro, which also includes the municipalities of São Gonçalo, Maricá, Itaboraí, Tanguá, Silva Jardim and Rio Bonito. Appointments were made with the MV2000 - Hospital information system, used at HUAP since 2006. The study period ran from March 2006 to December
2013. The data were collected from prenatal records, via previously validated protocols.

All the records of pregnant women registered in the system were eligible for inclusion in the study, reaching a total of 13,771 attendances (first and subsequent prenatal appointments). Finally, 635 randomly generated records were selected by querying the Oracle database of the MV2000 system. General variables such as age, municipality of origin, year of follow-up, gestational age, prenatal risk, number of visits performed during prenatal care, previous obstetric and clinical history, intercurrences during pregnancy or delivery, beginning of sexual life, number of partners, gestational outcome, and specific variables such as history of vaccination for hepatitis B and the results of viral markers for hepatitis B and C. As for age, patients were categorized into three groups: under 20, 20 to 35 and over 35 years of age. For the purpose of this study, the frequency of prenatal appointments was categorized into three groups and considered "insufficient" (less than six visits), "adequate" (six to ten visits) and "optimal" (more than ten visits). Regarding the number of pregnancies, the women were divided into three groups: primigravidae (single gestation), multiparous (between two and three gestations) and large multiparous (above three gestations). The gestational outcomes considered were vaginal delivery, cesarean section, abortion and ignored (delivered elsewhere than in HUAP and not reported in the medical record). In "reported vaccination" there were three possible answers: yes, no, unknown (not mentioned in the medical records). The viral markers were defined as positive, negative and absent (not requested or the result was not documented in the medical record). The database was built in the Microsoft Office Access program and was later exported to Microsoft Office Excel. For the processing and analysis of the data, it was used the SPSS (Statistical Package for Social Science, IBM) version 22.0, for Windows. For the age, the average, standard deviation (SD), median and confidence interval (CI) were calculated. This variable was also explored by verifying the distribution of normality, to test the established hypotheses. From the Kolmogorov-Smirnov test it was defined that the Mann-Whitney test would be used to verify the existence of significant differences between the ranked averages of the ages in the groups of viral markers, positive and negative. The Kruskal-Wallis tests with Tukey's post-Hoc test were used to verify if there was a difference between the years of research (eight categories) and the age of the pregnant women. Categorical variables were analyzed via relative and absolute frequency tables. To verify the possible association between these variables, the Chi-square test was conducted, employing the Fisher's exact test. In addition to the verification of the $P$-value, in the binary tabulations, the odds ratio was established observing the absence of the number 1 in the CI 95\%. All tests presented $P<0.05$. The research complied with Resolution 196/1996, which deals with research with human beings and was approved by the Research Ethics Committee of the Universidade Federal Fluminense (UFF), under opinion 977.674/2015 and CAAE 41681014.6.0000.5243.

\section{RESULTS}

The age of pregnant women varied from 12 to 46 years, with median and average of 27 years (26.4-27.5), with standard deviation \pm 6.92 (SD). In relation to the age groups, there were 98 women under the age of 20, 465 women between 20 and 35 years and 72 of them over the age of 35 years. There was no significant difference between the age of the patients during the years of research $(P=0.384)$. The 
number of appointments ranged from 1 to 16 , with an average of 7. An adequate number of appointments predominated in women over 35 years of age. The number of pregnancies ranged from 1 to 8 (average of 2.3). From 469 completed deliveries, $164(34.9 \%)$ were vaginally and $305(65.1 \%)$ were delivered via cesarean section. The main indications of cesarean section were: iterativity, cephalopelvic disproportion and acute fetal distress. The clinical-demographic characteristics of the study population are summarized in TABLE 1.

TABLE 1. Clinical-demographic characteristics of pregnant women attended by age group in HUAP during the 2006-2013 period.

\begin{tabular}{|c|c|c|c|c|}
\hline \multirow[b]{2}{*}{ Variables } & \multicolumn{3}{|c|}{ Age Group } & \multirow[b]{2}{*}{ Total } \\
\hline & $\begin{array}{c}<20 \text { years } \\
(\mathrm{N}=98)\end{array}$ & $\begin{array}{c}20-35 \text { years } \\
(\mathrm{N}=465)\end{array}$ & $\begin{array}{l}>35 \text { years } \\
(\mathrm{N}=72)\end{array}$ & \\
\hline Research year & $\mathrm{n}(\%)$ & $\mathrm{n}(\%)$ & $\mathrm{n}(\%)$ & $\mathrm{n}_{\mathrm{t}}(\%)$ \\
\hline 2006 & $17(17.3)$ & $71(15.2)$ & $9(12.5)$ & $97(15.3)$ \\
\hline 2007 & $21(21.5)$ & $84(18.2)$ & $14(19.5)$ & $119(18.7)$ \\
\hline 2008 & $10(10.2)$ & $62(13.3)$ & $11(15.3)$ & $83(13.1)$ \\
\hline 2009 & $10(10.2)$ & $36(7.7)$ & $5(6.9)$ & $51(8.1)$ \\
\hline 2010 & $13(13.3)$ & $47(10.2)$ & $5(6.9)$ & $65(10.2)$ \\
\hline 2011 & $6(6.1)$ & $58(12.5)$ & $12(16.7)$ & $76(12.0)$ \\
\hline 2012 & $11(11.2)$ & $57(12.2)$ & $11(15.3)$ & $79(12.4)$ \\
\hline 2013 & $10(10.2)$ & $50(10.7)$ & $5(6.9)$ & $65(10.2)$ \\
\hline $\begin{array}{l}\text { Municipality } \\
\text { of origin }\end{array}$ & $\mathrm{n}(\%)$ & $\mathrm{n}(\%)$ & $\mathrm{n}(\%)$ & $\mathrm{n}_{\mathrm{t}}(\%)$ \\
\hline Niterói & $42(42.8)$ & $208(44.7)$ & $35(48.6)$ & $285(44.9)$ \\
\hline São Gonçalo & $38(38.8)$ & $176(37.8)$ & $26(36.1)$ & $240(37.8)$ \\
\hline Others & $18(18.4)$ & $81(17.5)$ & $11(15.3)$ & $110(17.3)$ \\
\hline At risk & $\mathrm{n}(\%)$ & $\mathrm{n}(\%)$ & $\mathrm{n}(\%)$ & $\mathrm{n}_{\mathrm{t}}(\%)$ \\
\hline Yes & $66(67.3)$ & $322(69.2)$ & $65(90.3)$ & $453(71.3)$ \\
\hline No & $32(32.7)$ & $143(30.8)$ & $7(9.7)$ & $182(28.7)$ \\
\hline Gestations & $\mathrm{n}(\%)$ & $\mathrm{n}(\%)$ & $\mathrm{n}(\%)$ & $\mathrm{n}_{\mathrm{t}}(\%)$ \\
\hline 1 & $72(73.4)$ & $124(26.7)$ & $7(9.7)$ & $203(32.0)$ \\
\hline $2-3$ & $23(23.5)$ & $244(52.5)$ & $39(54.2)$ & $306(48.2)$ \\
\hline$>3$ & $3(3.1)$ & $97(20.8)$ & $26(36.1)$ & $126(19.8)$ \\
\hline Appointments & $\mathrm{n}(\%)$ & $\mathrm{n}(\%)$ & $\mathrm{n}(\%)$ & $n_{t}\left(n_{t} \%\right)$ \\
\hline$<6$ & 44 (44.9) & $150(32.3)$ & $18(25.0)$ & $212(33.4)$ \\
\hline $6-10$ & $40(40.8)$ & $229(49.2)$ & $40(55.5)$ & 309 (48.6) \\
\hline$>10$ & $14(14.3)$ & $86(18.5)$ & $14(19.5)$ & $114(18.0)$ \\
\hline Outcome & n (\%) & n (\%) & $\mathrm{n}(\%)$ & $\mathrm{n}_{\mathrm{t}}(\%)$ \\
\hline $\begin{array}{l}\text { Vaginal } \\
\text { delivery }\end{array}$ & $32(32.6)$ & $114(24.5)$ & $18(25.0)$ & $164(25.8)$ \\
\hline $\begin{array}{l}\text { Cesarean } \\
\text { section }\end{array}$ & $35(35.7)$ & $231(49.7)$ & $39(54.1)$ & $305(48.0)$ \\
\hline Abortions & $3(3.1)$ & $7(1.5)$ & $3(4.2)$ & $13(2.1)$ \\
\hline Ignored & 28 (28.6) & $113(24.3)$ & $12(16.7)$ & $153(24.1)$ \\
\hline Intercurrences & $\mathrm{n}(\%)$ & n (\%) & $\mathrm{n}(\%)$ & $\mathrm{n}_{\mathrm{t}}(\%)$ \\
\hline Yes & $38(38.8)$ & $154(33.1)$ & $25(34.7)$ & $217(34.2)$ \\
\hline $\begin{array}{l}\text { Not } \\
\text { reported }\end{array}$ & $60(61.2)$ & 311 (66.9) & $47(65.3)$ & $418(65.8)$ \\
\hline
\end{tabular}

$\mathrm{N}$ : number of patients evaluated; $\mathrm{n}$ : total per variable; $\mathrm{n}_{\mathrm{r}}(\%)$ total per variable/percentage of the total number of patients evaluated $(\mathrm{N}=635)$.
As for the viral markers, 12 (12/631) returned positive HBsAg $(1.9 \%), 189(189 / 526)$ positive anti-HBs $(35.9 \%)$ and seven $(7 / 560)$ positive $\mathrm{HCV}(1.3 \%)$. The response to $\mathrm{HBV}$ vaccination was positive in $23(3.6 \%)$ patients and negative in $35(5.5 \%)$. This information was not included in $577(90.9 \%)$ medical records. The results of the hepatitis $\mathrm{B}$ and $\mathrm{C}$ markers and the vaccination history for HBV and markers per year of this survey can be seen in TABLE 2 and FIGURE 1 respectively.

TABLE 2. Serological markers of hepatitis $B$ and $C$ and vaccination history against hepatitis B virus by age group evaluated. HUAP/2006-2013.

\begin{tabular}{|c|c|c|c|c|}
\hline \multirow[b]{2}{*}{ Variáveis } & \multicolumn{3}{|c|}{ Age Group } & \multirow[b]{2}{*}{ Total } \\
\hline & $\begin{array}{c}<20 \text { years } \\
(\mathrm{N}=98)\end{array}$ & $\begin{array}{c}20-35 \text { years } \\
(\mathrm{N}=465)\end{array}$ & $\begin{array}{c}>35 \\
\text { years } \\
(\mathbf{N}=72)\end{array}$ & \\
\hline $\mathrm{HBsAg}$ & $\mathrm{n}(\%)$ & $\mathrm{n}(\%)$ & $\mathrm{n}(\%)$ & $\mathrm{n}_{\mathrm{t}}(\%)$ \\
\hline Positive & $1(1.0)$ & $11(2.4)$ & - & $12(1.9)$ \\
\hline Negative & $97(99.0)$ & $451(97.0)$ & 71 (98.6) & $619(97.5)$ \\
\hline Not listed & - & $3(0.6)$ & $1(1.4)$ & $4(0.7)$ \\
\hline Anti-HBs & $\mathrm{n}(\%)$ & $\mathrm{n}(\%)$ & $\mathrm{n}(\%)$ & $\mathrm{n}_{\mathrm{t}}(\%)$ \\
\hline Positive & $38(38.8)$ & $139(29.9)$ & $12(16.7)$ & $189(29.8)$ \\
\hline Negative & 44 (44.9) & $246(52.9)$ & $47(65.3)$ & $337(53.1)$ \\
\hline Not listed & $16(16.3)$ & $80(17.2)$ & $13(18.0)$ & $109(17.2)$ \\
\hline Anti-HCV & $\mathrm{n}(\%)$ & $\mathrm{n}(\%)$ & $\mathrm{n}(\%)$ & $\mathrm{n}_{\mathrm{t}}(\%)$ \\
\hline Positive & $1(1.0)$ & $5(1.1)$ & $1(1.4)$ & $7(1.1)$ \\
\hline Negative & $83(84.7)$ & $408(87.7)$ & $62(86.1)$ & $553(87.1)$ \\
\hline Not listed & $14(14.3)$ & $52(11.2)$ & $9(12.5)$ & $75(11.8)$ \\
\hline $\begin{array}{l}\text { Vacinação } \\
\text { contra HBV }\end{array}$ & $\mathrm{n}(\%)$ & $\mathrm{n}(\%)$ & $\mathrm{n}(\%)$ & $\mathrm{n}_{\mathrm{t}}(\%)$ \\
\hline Yes & $5(5.1)$ & $17(3.7)$ & $1(1.4)$ & $23(3.6)$ \\
\hline No & $7(7.1)$ & $26(5.6)$ & $2(2.8)$ & $35(5.5)$ \\
\hline Unknown & $86(87.8)$ & $422(90.7)$ & $69(95.8)$ & 577 (90.9) \\
\hline
\end{tabular}

$\mathrm{N}$ : number of patients evaluated; $\mathrm{n}$ : total per variable; $\mathrm{n}_{\mathrm{r}}(\%)$ : number of cases found in the total number of cases evaluated for each variable.

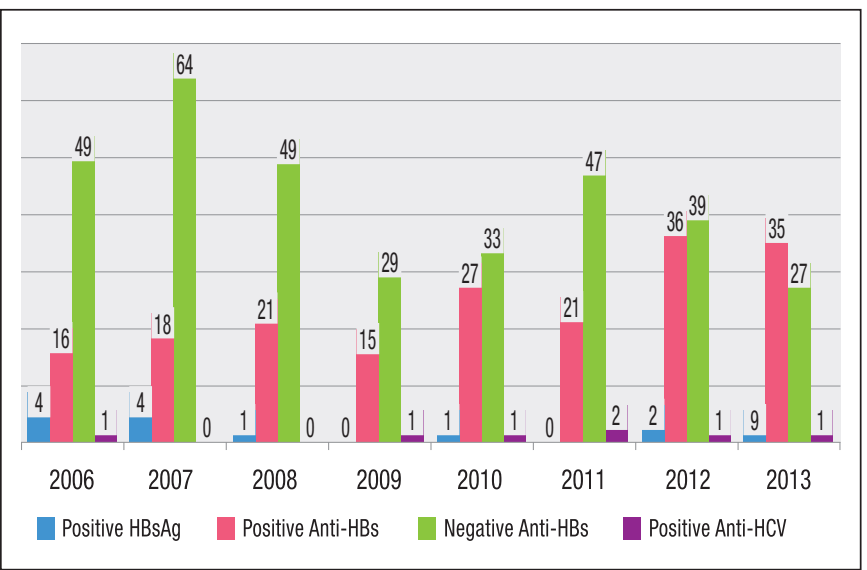

FIGURE 1. Result of the main viral markers per year of research. HUAP/2006-2013. 
The positive HBsAg cases predominated in the 20-35-year-old age group (90\%), with an average of 26 years, but according to the Mann-Whitney test, the difference between the age groups was not significant $(P=0.205)$. There was a prevalence of positive HBsAg cases in the years 2006, 2007 and 2012 (over 80\%) - FIGURE 1. According to the number of pregnancies, $41 \%$ were primigravidae and $58 \%$ were multiparous. Regarding the history of previous vaccination, six women denied having been vaccinated for hepatitis B and in six cases this fact was unknown. Other possible risk factors for HBV infection were identified in only three cases: habitual use of injectable medication due to chronic disease, drug-using sexual partner and mother with hepatitis $\mathrm{B}$, the latter suggesting vertical HBV transmission. The diagnosis in $67 \%$ of the cases was carried out in prenatal care. It was possible to identify, according to reports in the medical records, four cases of inactive patients with $\mathrm{HBsAg}$, one of acute hepatitis already in convalescence and two of patients with chronic hepatitis, one positive $\mathrm{HBeAg}$ and the other negative $\mathrm{HBeAg}$. There was no case of co-infection with HCV.

Anti-HBs were positive in 189 cases $(34.2 \%)$, with predominance in the $20-35$ years age group $(73.5 \%)$, with the average age in this range being 26.1 years. These positive results were more observed from the year 2010 onwards, especially in the 20-35 years age group and $47 \%$ of cases from 2006 to 2013 . Only in 2013 the number of cases with positive anti-HBs was higher than that of negative antiHBs (FIGURES 1 AND 2). There was a direct relationship between positive anti-HBs and the last four years (2010-2013) of the study $(P<0.001 ; \mathrm{OR}=2.22 ; 95 \% \mathrm{CI}:-1.543-3.205)$, but this relationship was not confirmed for the variable "age", when compared with the years of research $(P=0.872)$. There is a direct relationship between the anti-HBs positivity and the positive history for previous vaccination against hepatitis $\mathrm{B}(P=0.001$; OR $=8,125$; CI 95\%= 2.208-29.901). FIGURE 3 displays the vaccination history for $\mathrm{HBV}$ and the relationship with the result of anti-HBs over the years of research.

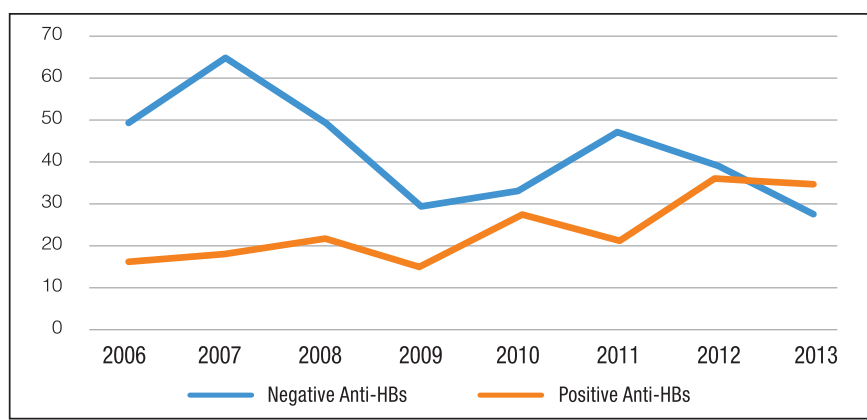

FIGURE 2. Outcome of anti-HBs over the years of research. HUAP/ 2006-2013.

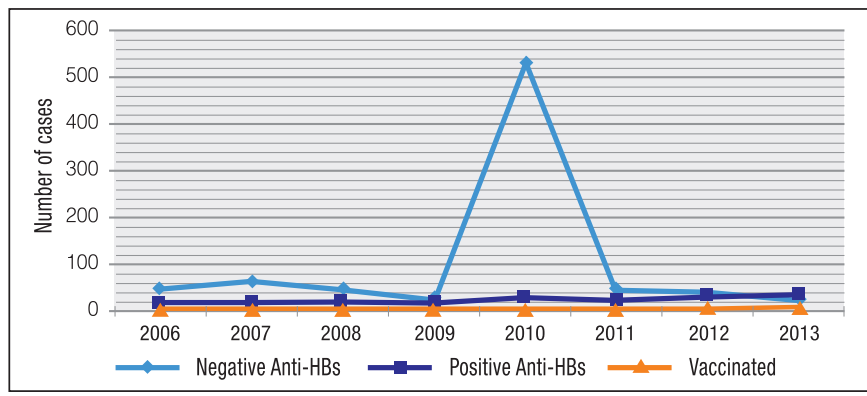

FIGURE 3. Relationship between positive history for vaccination and positive and negative Anti-HBs. HUAP/2006-2013.
In the first three years of the study period (2006-2009) antiHBs were negative in 162 cases, representing $48 \%$ of the negative cases in these years. From 2009 onwards, negative anti-HBs were proportionally less frequent, although peaks were observed in 2011 and 2012 (FIGURE 3). There was no significant difference between the average age of patients that returned positive and negative for anti-HBs $(P=0.907)$.

Seven patients with HCV-positive serologies $(1.3 \%)$ were identified, and five cases $(71.4 \%)$ were diagnosed in the prenatal period. The age ranged from 18 to 46 years, with a mean of 28.8 years and blood transfusion was considered a risk factor for three patients, and it was not possible to identify the presence of risk factors for the remaining cases.

\section{DISCUSSION}

In the pregnant women group, average maternal age was 27 years, outlining the profile of pregnant women as a young population that, from a reproductive point of view, is considered optimal because it represents a lower perinatal risk ${ }^{(16)}$. There was a significant percentage of pregnant adolescents (younger than 20 years) who reached $15.4 \%$ of the total number of women evaluated. Despite falling rates, the incidence of pregnant adolescents in Brazil is considered high, and it is estimated that $20 \%-25 \%$ of all pregnant women in Brazil are adolescents ${ }^{(17,18)}$. Manfré and collaborators $^{(19)}$ observed in a study on Latin America that among $25 \%$ of the poorest population, one in three births originates from an adolescent mother, increasing this proportion even more in rural areas. Pregnancy in this population group has been considered a public health problem in some countries, since it can lead to obstetric complications, with repercussions for the mother and the newborn, as well as psychosocial and economic problems ${ }^{(20)}$.

Late pregnancies (older than 35 years) have been increasing in Brazil and in the world, demonstrating a trend that is taking place mainly in industrialized countries and is considered a pre-existing gestational risk factor by the Ministry of Health, requiring special attention in prenatal care. Late pregnancy was observed in $11.3 \%$ of the women studied, lower than the $13.0 \%$ found in the literature ${ }^{(21,22)}$.

The fertility rate, which is an estimate of the number of children a woman has throughout her life, has been declining in Brazil since the end of the $1960 \mathrm{~s}$, from 2.4 to 1.8 in the period from 2000 to 2015 , but remained higher in the rural area, with about 2.7 children per woman. The Southeast Region has the lowest national average, equal to 1.75. Factors such as the expansion of urbanization, sexual education and family planning, with more widespread use of contraceptive methods, greater participation of women in the labor market, and higher costs of raising and educating children appear to be contributing to this decline. In the present study there was a predominance of multiparous, with the average number of pregnancies found in the evaluated period equal to 2.3, higher than that found for the Southeast region according to the demographic census of $2010^{(23)}$.

The definition of an ideal number of appointments is important for the elaboration of health care protocols and resource planning. The Prenatal and Birth Humanization Program makes it possible to classify as appropriate every prenatal follow-up initiated up to the fourth month of gestation with six or more appointments, one in the first trimester, two in the second and three in the third trimester ${ }^{(24)}$. The last National Demography and Health Survey, conducted in 2006, revealed a $80.9 \%$ coverage for prenatal care with 
six or more visits ${ }^{(25)}$. The average score was equal to seven visits, with $66.7 \%$ of the cases with more than six queries defined in this study as an optimal number, although this proportion is lower than the one observed in Brazil ${ }^{(26)}$. Inferior proportional adherence to the appointments was observed in the age of less than 20 years, and this fact was also demonstrated in studies conducted in other Brazilian regions, which showed an association between pregnancy in adolescence and a smaller number of prenatal appointments ${ }^{(27)}$. The highest percentage of appointments with a number greater than six $(75.0 \%)$ were found in the group above 35 years of age, probably because the pregnancies of elderly women have been considered as high risk, mainly due to increased incidence of hypertensive syndromes, premature rupture of membranes, presence of diabetes, and a greater chance of complications for the newborn ${ }^{(28)}$.

There was a predominance of cesarean delivery in this study, $65 \%$ of cases, even though WHO recommends that this percentage should not exceed $15 \%$. The prevalence of cesarean section over vaginal delivery occurred in all age groups evaluated. The high rate of cesarean deliveries in the Brazilian context stands out as alarming, especially when compared to data of countries with low rates $(14.0 \%-18.0 \%)$ such as the Netherlands, Czech Republic, Slovakia, Norway and Sweden and even those with rates considered high $(30.0 \%-33.0 \%)$ such as the United States, Portugal, Australia, Korea, Italy and Mexico ${ }^{(29)}$. It is important to note that the HUAP prenatal outpatient clinic is a reference for pregnancy with any type of risk, obstetric or not, and that, of the cases studied here, more than $71 \%$ were pregnant women considered to be at risk.

The prenatal blood tests represent a valuable opportunity for the diagnosis of hepatitis B and its manifestations, contributing to the decrease of the prevalence of this disease and its complications. Machado Filho et al. reported a variation of the prevalence of $\mathrm{HBsAg}$ from $0.3 \%$ to $1.7 \%$ in Brazil, except in some regions of the Amazon. Similar data are found in other countries, except in regions of Africa and Asia where prevalence can reach up to $15 \%{ }^{(30)}$ In an epidemiological study conducted in Brazil, the overall prevalence of the HBsAg marker for the Brazilian capitals was $0.37 \%{ }^{(6)}$.

In pregnant women, the prevalence of hepatitis B varies according to the endemicity of the infection in the geographic region and population studied. However, there are few studies on the screening of the disease in the gestational period in Brazil, especially in the state of Rio de Janeiro. Souza et al. reported a prevalence of chronic HBV among Brazilian pregnant women ranging from $0.5 \%$ to $8.7 \%$, depending on the region studied ${ }^{(5)}$

Twelve women positive for HBsAg were detected in this study, with an estimated prevalence of $1.9 \%$. This prevalence varied according to the years of research when the cases were observed (4.1\% in 2006, 3.4\% in 2007, $1.2 \%$ in $2008,1.5 \%$ in 2010 and $2.5 \%$ in 2012). Contrary to the literature ${ }^{(31)}$, in this study there was no growth in its prevalence with the increase in age.

In the Rio de Janeiro state, the detection rate of Hepatitis B showed significant growth until 2009, displaying a decrease in 2010 , with a new increase in 2011, exhibiting a new downward trend as of $2012^{(32)}$

The prevalence of HBV presented here has important implications for both health managers and for the effectors of the health service, especially physicians involved in its care, and emphasize the importance of carrying out similar surveys in this region.

Studies on the vertical transmission of hepatitis B are rare in Brazil, since the HBsAg research began to compose the prenatal routine only after $2005^{(33)}$. The Ministry of Health, through the
Epidemiological Bulletin of Viral Hepatitis, presented the vertical transmission of hepatitis B as the third most frequent category of infection, only below the sexual and domiciliary contact, and the reported transmission rate was $5.9 \%$ (4).

In the presence of chronic HBV, a greater incidence of maternal and fetal complications has been reported if compared to the rest of the population, but these data are still conflicting ${ }^{(34)}$. In five cases of positive HBsAg patients, complications related specifically to gestation (retrocorionic hematoma, oligohydramnios and premature amniorrexis) were found. In relation to newborns, prematurity was reported in three cases. There were insufficient data in the records to assess possible cases of $\mathrm{HBV}$ via vertical transmission.

In the absence of maternal antiviral treatment or immunoprophylaxis when indicated, the chronification percentage of HBV-infected newborn by vertical transmission may reach $90 \%$, with an increased risk of developing disease-related complications at an early stage in life ${ }^{(7,15,35)}$. In the $1990 \mathrm{~s}$, WHO recommended that hepatitis $B$ vaccination must be incorporated into national vaccination programs. Also in this same decade the vaccine was offered by the SUS. Since 1998, the National Immunization Program of the Ministry of Health has begun to recommend universal vaccination of children from birth ${ }^{(36)}$.

Anti-HBs were positive in 189 pregnant women. This positivity was more observed as of 2010, especially in the 20-35 age group, and 2013 was the only year in which the number of cases with positive anti-HBs was higher than those with negative anti-HBs. This direct relationship between the anti-HBs positivity and the last years of the research was statistically significant $(P<0.0001)$ and probably related to the improvement of vaccination coverage in the country in recent years.

The low relative immunization rate observed in this population of pregnant women requires better investigation and should be clarified if it was due to an inadequate medical recommendation for vaccination or the noncompliance of the patients to this recommendation, or if it was the result of a possible defective immune response to the vaccination.

Regarding HCV in the evaluated group, seven patients with positive anti-HCV were identified, with a global prevalence estimated at $1.3 \%$. The prevalence found in this research was higher than those reported by Nunes and collaborators $(0.1 \%)^{(37)}$, Rodrigues Neto et al. $(0.3 \%)^{(38)}$ and Carvalho et al. $(0.9 \%)^{(39)}$, but similar to that found in a 2010 study led by researchers from University of Pernambuco ${ }^{(40)}$, in which the prevalence of all Brazilian capitals was $1.38 \%$. Licata and collaborators ${ }^{(41)}$ reported a prevalence among pregnant women between $1 \%$ and $2 \%$ in the United States and Europe but could reach up to $8 \%$ in developing countries.

Studies in Brazil did not detect differences between the prevalence of hepatitis $\mathrm{C}$ in pregnant women and in the general population $^{(42)}$. However, these prevalences may be underestimated since the practice of screening was adopted only in pregnant women belonging to groups that are more likely to be infected and may ignore a large number of $\mathrm{HCV}$ cases ${ }^{(43)}$. According to WHO, Brazil is considered a country of intermediate endemicity. However, population-based and blood donor studies revealed lower prevalences than those estimated, placing Brazil as low endemicity ${ }^{(4,5,7)}$. This divergence is probably explained by the use of seroprevalence studies in specific groups that do not necessarily represent the general population $^{(39)}$.

The age of positive anti-HCV patients in the present study ranged from 18 to 46 years, with an average of 28.8 years (SD 
$\pm 9.04)$. Pereira and collaborators ${ }^{(44)}$ reported an increase in exposure to $\mathrm{HCV}$ with age. Oliveira et al. ${ }^{(45)}$ also observed an association between positive anti-HCV and age over 40 years. In their study, Wang and colleagues ${ }^{(46)}$ suggested that hepatitis $\mathrm{C}$ affects people of all ages, but there is a peak incidence between 20 and 39 years of age and a higher prevalence rate in the 30-49 years range. In the casuistry of the present study, six patients were older than 25 years and all were born before 1989 and no statistically significant difference was observed in age and anti-HCV positivity $(P=0.676)$.

As in the case of hepatitis $B$, hepatitis $C$ transmission is relatively stable in Brazil in terms of number of new cases diagnosed each year during the period between 2004 and 2014, except for 2013. The majority of cases reported in Brazil are concentrated in the Southeast and South regions ${ }^{(4)}$. In any case, the HCV in pregnant women addresses the need for a routine investigation of this infectious disease during prenatal care. Vertical HCV transmission is less frequent than that of HBV and might encompass between $3 \%$ and $10 \%$ of the cases ${ }^{(47,48)}$. The patients in this study had no complications during pregnancy or childbirth attributable to $\mathrm{HCV}$. Intercurrences with newborns were also not reported.

\section{FINAL CONSIDERATIONS}

This is the first study that evaluates the seroprevalence of hepatitis $\mathrm{B}$ and $\mathrm{C}$ in pregnant women attended in the city of Niteró $(\mathrm{RJ})$ and, although it is limited to the population of pregnant women attended at HUAP and does not represent the population as a whole, it can serve as a base for the adoption of public policies in the municipal and state scenario, contributing to changes. A high prevalence of $\mathrm{HBV}$, above that expected for the region, was observed; a prevalence for HCV consistent with the current Brazilian reality; a low rate of hepatitis $\mathrm{B}$ immunization, with a high index of susceptibility to this infection; and no case of co-infection.

The availability of the vaccine against HBV and the appearance of new drugs that can control the chronic disease, besides the knowledge of measures that prevent transmission, including vertical transmission, has a real chance of controlling this disease.

To prevent the prevalence of $\mathrm{HCV}$ from continuing to increase worldwide, a global effort is needed to strengthen care for primary prevention, including the development of vaccines and new approaches to secondary and tertiary prevention, reducing cases of chronic liver disease and improving the survival of the carriers.

There is a need to encourage research on the prevalence and incidence of these diseases in pregnant women, in order to plan strategies for prevention, prophylaxis and treatment of these infections, avoiding the damaging effects on the mother and her child and consequently raising costs to the health system.

It is important to carry out more research in pregnant women in this area as well as the prenatal screening of hepatitis B and $\mathrm{C}$, with no exceptions, since even though the current advances in therapy may not cure, at least they may allow a better quality of life for patients with chronic disease. It is also emphasized the need for mandatory immunoprophylaxis for all newborns and special attention should be given to those patients susceptible to HBV, with prompt diagnosis and referral for specific vaccination.

\section{Authors' contribution}

Barros MMO performed the research and wrote the paper; Ronchini KROM and Soares RLS designed the research and analyzed the data.

Barros MMO, Ronchini KROM, Soares RLS. Hepatite B e C em gestantes atendidas em um programa de pré-natal em um hospital universitário no Rio de Janeiro, Brasil: estudo retrospectivo de rastreamento da soroprevalência. Arq Gastroenterol. 2018,55(3):267-73.

RESUMO - Contexto - As hepatites pelo vírus B e C são doenças com elevada morbimortalidade e um problema de saúde pública global. No Brasil a prevalência não é homogênea, variando entre as diferentes regiões, mas estima-se que atualmente cerca de 1\% da população apresente doença crônica relacionada ao vírus B e que haja 1,5 milhões de infectados pelo vírus C. Apesar do desenvolvimento da vacina contra a hepatite B, da melhoria nos métodos diagnósticos e dos avanços terapêuticos no campo das hepatites virais, ainda é grande o número de pessoas que continuam sendo infectadas por esses vírus, principalmente nas populações sob algum tipo de risco e devido a vários fatores incluindo políticas de vacinação e migração. A transmissão vertical e também a perinatal têm grande importância na epidemiologia das hepatites virais e os exames realizados durante o pré-natal constituem uma oportunidade única de rastreio e identificação destes vírus. Objetivo - Avaliar a soroprevalência de marcadores para os vírus B e C em mulheres que realizaram a assistência pré-natal no Hospital Universitário Antônio Pedro no período de 2006 a 2013 e comparar os resultados encontrados com os dados regionais e os descritos na literatura específica. Métodos - Estudo transversal, descritivo, do tipo quantitativo, com coleta retrospectiva de dados em 635 prontuários de gestantes atendidas no Serviço de pré-natal do Hospital Universitário Antônio Pedro, Niterói, estado do Rio de Janeiro no período de março de 2006 a dezembro de 2013. O banco de dados foi construído no programa Microsoft Office Access, sendo posteriormente exportado para Microsoft Office Excel. Para o processamento e análise dos dados, foi utilizado o pacote estatístico SPSS (Statistical Package for Social Science, IBM) versão 22.0, para Windows. Resultados - Foram observados 12 casos com HBsAg positivo (1,9\%), 189 casos com anti-HBs positivo $(35,9 \%)$ e sete pacientes positivas para o anti-HCV $(1,3 \%)$. Não foi observada associação significativa entre a faixa etária e a positividade do HBsAg, anti-HBs e anti-HCV $(P=0,205,0,872$ e 0,676 respectivamente). Houve relação direta entre a positividade do anti-HBs e os últimos quatro anos da pesquisa $(P<0,0001)$. Conclusão - Foi observada uma prevalência alta do HBsAg, acima daquela esperada para a região avaliada; uma prevalência para o anti-HCV concordante com a realidade brasileira atual; um índice provavelmente baixo de imunização contra a hepatite B, com índice relativamente alto de susceptibilidade para esta infecção e nenhum caso de coinfecção entre o vírus B, C e o HIV. Enfatiza-se não só a necessidade da triagem das hepatites B e C, sem exceções, durante o pré-natal, já que os avanços atuais na terapêutica poderão se não curar, pelo menos possibilitar uma melhor qualidade de vida para as pacientes com doença crônica e da realização mandatória da imunoprofilaxia em todos os recém-natos. Atenção especial deverá ser dada àquelas pacientes susceptíveis ao HBV, com pronto diagnóstico e encaminhamento para a realização da vacinação específica.

DESCRITORES - Estudos soroepidemiológicos. Hepatite B. Hepatite C. Gravidez. Gestantes. 


\section{REFERENCES}

1. EASL. Clinical Practice Guidelines on the management of hepatitis B virus infection. European Association for the Study of the Liver. J Hepatol. 2017;67 $370-98$.

2. Terrault NA, Bzowej NH, Chang KM, Hwang JP, Jonas MM, Murad MH. AASLD Guidelines for treatment of chronic hepatitis B. Hepatology. 2016;63:261-83.

3. Brasil. Ministério da Saúde, Secretaria de Vigilância em Saúde Departamento de Vigilância, Prevenção e Controle das Infecções Sexualmente Transmissíveis, do HIV/Aids e das Hepatites Virais - Protocolo clínico e diretrizes terapêuticas para hepatite B e coinfecções. DF, 2017.

4. Brasil. Ministério da Saúde. Secretaria de Vigilância em Saúde Departamento de Vigilância, Prevenção e Controle das Infecções Sexualmente Transmissíveis, do HIV/Aids e das Hepatites Virais- Boletim epidemiológico - Hepatites virais no Brasil. 2017; v.48, n.24.

5. Souza MT, Pinho TL, Santos MD, Santos AD, Monteiro VL, Fonseca LM et al. Prevalence of hepatites B among pregnant women assisted at the public maternity hospitals of São Luís, Maranhão. Braz J Infect Dis. 2012;16:517-20.

6. Ximenes RAA, Pereira LMB, Martelli CMT, Merchán-Hamann E, Stein AT, Figueiredo GM, et al. Methodology of a nationwide cross-sectional survey of prevalence and epidemiological patterns of hepatitis $\mathrm{A}, \mathrm{B}$ and $\mathrm{C}$ infection in Brazil. Cad Saúde Pública. 2010;26(9):1693-704.

7. Souto FJD. Distribution of hepatitis B infection in Brazil: the epidemiological situation at the beginning of the 21 st century. Rev Soc Bras Med Trop. 2015;49(1).

8. World Health Organization (WHO). Hepatitis C fact sheet updated October 2017. [Accessed 2017 Nov 29]. [Internet]. Available from: http://www.who.int/ mediacentre/factsheets/fs $164 / \mathrm{en} /$.

9. Mohamed AA, Elbedewy TA, El- Serafy M, El-Toukhy N, Ahmed W, Ali El Din Z. Hepatitis C virus: a global view. World J Hepatol. 2015;7:2676-80.

10. Messina JP, Humphreys I, Flaxman A, Brown A, Cooke GS, Pybus OG et al. Global distribution and prevalence of hepatitis $\mathrm{C}$ virus genotypes. Hepatology. 2015;61:77-87.

11. Kretzer IF, do Livramento A, da Cunha J, Gonçalves S, Tosin I, Spada C, et al. Hepatitis $\mathrm{C}$ worldwide and in Brazil: silent epidemic-data on disease including incidence, transmission, prevention, and treatment. Scientific World Journal. 2014; 2014:827849.

12. Andrade AF, Oliveira-Silva M, Silva SG, Motta IJ, Bonvicino CR. Seroprevalence of hepatitis B and C virus markers among blood donors in Rio de Janeiro, Brazil, 1998-2005. Mem Inst Oswaldo Cruz, Rio de Janeiro. 2006;101(6):673-6.

13. Bruggmann P, Berg T, Øvrehus AL, Moreno C, Brandão Mello CE, Roudot-Thoraval $\mathrm{F}$ et al. Historical epidemiology of hepatitis $\mathrm{C}$ virus (HCV) in selected countries. J Viral Hepat. 2014;21(Suppl 1):5-33.

14. Perim B, Passos ADC. Hepatite B em gestantes atendidas pelo Programa Pré-natal da Secretaria Municipal de Saúde de Ribeirão Preto, Brasil: prevalência da infecção e cuidados prestados aos recém-nascidos. Rev Bras Epidemiol. 2005;8:272-81.

15. World Gastroenterology Organization Global Guideline (WGO Global) Guideline Hepatitis B Version 2.0, February 2015. [Accessed 2017 Sept 11]. [Internet]. Available from: http://www.worldgastroenterology.org/guidelines/global-guidelines/ hepatitis-b/hepatitis-b-english.

16. Lima GSP, Sampaio HAC. Influência de fatores obstétricos, socioeconômicos e nutricionais da gestante sobre o peso do recém-nascido: estudo realizado em uma maternidade em Teresina, Piauí. Obstetric, social, economic and nutritional factors of pregnant women of newborn weight: study accomplished in a maternity in Teresina, Piauí. Rev. Bras. Saude Mater. Infant. 2004;4:253-61.

17. Brasil. Ministério da Saúde, 2012. Saúde Brasil 2011: uma análise da situação de saúde e a vigilância da saúde da mulher. Brasília: MS/SVS.

18. Brasil. Ministério da Saúde. Indicadores e Dados Básicos - Brasil. 2012. (IDB2012). Ministério da Saúde/SVS - Sistema de Informações sobre Nascidos Vivos (Sinasc).

19. Manfré CC, Queiróz SG, Matthes ACS. Considerações atuais sobre gravidez na adolescência. Rev Bras Med Fam Comunidade. 2010;5:48-54.

20. Yazlle MEHD. Gravidez na adolescência. Rev Bras Ginecol Obstet. 2006;28:443-5.

21. Gravena AAF, Sass A, Marcon SS, Pelloso SM. Resultados perinatais em gestações tardias. Rev. Esc. Enferm. USP. 2012;46:15-21.

22. Santos GHN, Martins, MG, Sousa MS, Batalha SJC. Impacto da idade materna sobre os resultados perinatais e via de parto Rev Bras Ginecol Obstet. 2009;31: 326-34.

23. Brasil Ministério do Planejamento. Orçamento e Gestão. Instituto Brasileiro de Geografia e Estatística - IBGE. Censo Demográfico 2010 Características da população e dos domicílios Resultados do universo. Rio de Janeiro; 2011.

24. Brasil. Diário Oficial da União. Portaria $n^{\circ} .569$, de $1^{\circ}$ de junho de 2000 . Institui o Programa de Humanização no Pré-natal e Nascimento no âmbito do SUS.
25. Viellas EF, Domingues RMSM, Dias MAB, Gama SGN, Filha MMT, Costa JV, et al. Assistência pré-natal no Brasil. Cad. Saúde Pública. 2014;30(Suppl 1):S85-S100.

26. Gomes RMT, César JA. Perfil epidemiológico de gestantes e qualidade do pré-natal em unidade básica de saúde em Porto Alegre, Rio Grande do Sul, Brasil. Rev Bras Med Fam Comunidade. 2013;8:80-9.

27. Alter MJ. Epidemiology of hepatitis B in Europe and worldwide. J Hepatol. 2003;39(Suppl 1):S64-S69.

28. Gravena AAF, Paula MG, Marcon SS, Carvalho MDB, Pelloso SM. Idade materna e fatores associados a resultados perinatais. Acta Paul. Enferm. 2013;26:130-5.

29. Brasil. Agência Nacional de Saúde Suplementar. O modelo de atenção obstétrica no setor de Saúde Suplementar no Brasil: cenários e perspectivas / Agência Nacional de Saúde Suplementar. Rio de Janeiro: ANS, 2008. 158 p.

30. Filho ACM, Sardinha JFJ, Ponte RL, Costa EP, Silva SS, Martinez-Espinosa FE. Prevalência de infecção por HIV, HTLV, VHB e de sífilis e clamídia em gestantes numa unidade de saúde terciária na Amazônia ocidental brasileira. Rev Bras Ginecol Obstet. 2010;32:176-83.

31. Dwivedi M, Misra SP, Misra V, Pandey A, Pant S, Singh R, et al. Seroprevalence of hepatitis B infection during pregnancy and risk of perinatal transmission. Indian J Gastroenterol. 2011;30:66-71.

32. Governo do Estado do Rio de Janeiro. Secretaria de Estado de Saúde. Subsecretaria de Vigilância em Saúde/Superintendência de Vigilância Epidemiológica e Ambiental. Boletim Epidemiológico DST/AIDS e Hepatites Virais, 2014.

33. Kupek E, Oliveira, JF. Transmissão vertical do HIV, da sífilis e da hepatite B no município de maior incidência de AIDS no Brasil: um estudo populacional no período de 2002 a 2007. Rev. Bras. Epidemiol. São Paulo; 2012, v.15, n.3, p.478-87.

34. Pan CQ, Lee HM. Antiviral Therapy for Chronic Hepatitis B in Pregnancy Semin Liver Dis. 2013;33:138-46.

35. Shazia Parveen S, Shyamala.R, Janardhan Rao R, Rama Rao MV. Sero -prevalence of Hepatitis B surface antigen among pregnant women attending antenatal clinic in a teaching hospital. J Microbiol Biotech Res. 2012;2:343-5.

36. Halegoua-de Marzio D, Hann HW. Then and now: The progress in hepatitis B treatment over the past 20 years. World J Gastroenterol. 2014;20:401-13.

37. Nunes HM, Soares MCP, Sarmento, VP, Malheiros AP, Borges AM (in memoriam), Silva IS et al. Soroprevalência da infecção pelos vírus das hepatites A, B, C, D e E em município da região oeste do Estado do Pará, Brasil. Rev Pan-Amaz Saude, Ananindeua. 2016;7:55-62

38. Neto JR, Cubas MR, Kusma SZ, Olandoski M. Prevalência da hepatite viral C em adultos usuários de serviço público de saúde do município de São José dos Pinhais - Paraná. Rev Bras Epidemiol. 2012;15:627-63.

39. Carvalho JR, Portugal FB, Flor LS, Campos MR, Schramm JMA. Método para estimação de prevalência de hepatites B e C crônicas e cirrose hepática - Brasil, 2008. Epidemiol Serv Saúde. 2014;23:691-700.

40. Universidade de Pernambuco. Núcleo de Pós-Graduação. Estudo de prevalência de base populacional das infecções pelos vírus das hepatites A, B e C nas capitais do Brasil. Relatório de Pesquisa. Brasil; 2010.

41. Licata A, Ingrassia D, Serruto A, Soresi M, Giannitrapani L, Montalto G, et al. Clinical course and management of acute and chronic viral hepatitis during pregnancy. J Viral Hepat. 2015;22:515-23.

42. Brasil. Ministério da Saúde. Secretaria de Vigilância em Saúde Departamento de Vigilância, Prevenção e Controle das Infecções Sexualmente Transmissíveis, do HIV/Aids e das Hepatites Virais - Protocolo clínico e diretrizes terapêuticas para hepatite $\mathrm{C}$ e coinfecções. DF; 2017.

43. Prasad MR, Honegger JR. Hepatitis C virus in pregnancy. Am J Perinatol. 2013;30:149-59.

44. Pereira LM, Martelli CM, Moreira RC, Merchan-Hamman E, Stein AT, Cardoso $\mathrm{MR}$, et al. Prevalence and risk factors of Hepatitis C virus infection in Brazil, 2005 through 2009: a cross-sectional study. BMC Infect Dis. 2013;13:60.

45. Oliveira CV, Barbosa WF, Silveira LVA, Menezes J, Machado FS, Silva JF. Prevalence of the hepatitis C virus among university employees in São Paulo, Southeastern Brazil: predictive factors and geoprocessing spatial analysis. Arq Gastroenterol. 2015;52:9-13.

46. Wang CS, Wang ST, Yao WJ, Chang TT, Chou P. Hepatitis C virus infection and development of type 2 diabetes in a community-based longitudinal study. Am J Epidemiol. 2007;166:196-203.

47. Dunkelberg JC, Berkley EM, Thiel KW, Leslie KK. Hepatitis B and C in pregnancy: a review and recommendations for care. J Perinatol. 2014;34:882-91.

48. Floreani A. Hepatitis C and pregnancy. World J Gastroenterol. 2013;19:6714-20. 